\title{
Wildfire Effects on Source-Water Quality-Lessons from Fourmile Canyon Fire, Colorado, and Implications for Drinking-Water Treatment
}

Forested watersheds provide high-quality source water for many communities in the Western United States. These watersheds are vulnerable to wildfires, and wildfire size, fire severity, and length of fire season have increased since the middle 1980s (Westerling and others, 2006). Burned watersheds are prone to increased flooding and erosion, which can impair water-supply reservoirs, water quality, and drinking-water treatment processes. Limited information exists on the degree, timing, and duration of the effects of wildfire on water quality, making it difficult for drinking-water providers to evaluate the risk and develop management options.

In order to evaluate the effects of wildfire on water quality and downstream ecosystems in the Colorado Front Range, the U.S. Geological Survey initiated a study after the 2010 Fourmile Canyon fire near Boulder, Colorado. Hydrologists frequently sampled Fourmile Creek at monitoring sites upstream and downstream of the burned area to study water-quality changes during hydrologic conditions such as base flow, spring snowmelt, and summer thunderstorms.

This fact sheet summarizes principal findings from the first year of research. Stream discharge and nitrate concentrations increased downstream of the burned area during snowmelt runoff, but increases were probably within the treatment capacity of most drinking-water plants, and limited changes were observed in downstream ecosystems. During and after high-intensity thunderstorms, however, turbidity, dissolved organic carbon, nitrate, and some metals increased by 1 to 4 orders of magnitude within and downstream of the burned area. Increases of such magnitude can pose problems for water-supply reservoirs, drinking-water treatment plants, and downstream aquatic ecosystems.

\section{Study Rationale and Approach}

The degree to which wildfire degrades water quality and supply depends on wildfire extent and intensity, postwildfire precipitation, watershed topography, and local ecology. Potential effects of wildfire on municipal water supplies and downstream aquatic ecosystems include the following:

- Changes in the magnitude and timing of snowmelt runoff, which influence filling of water-supply reservoirs,

- Increased loading of streams by nutrients, dissolved organic carbon, major ions, and metals,

- Postfire erosion and transport of sediment and debris to downstream water-treatment plants, water-supply reservoirs, and aquatic ecosystems, and

- Changes in source-water chemistry that can alter drinkingwater treatment.

The Fourmile Canyon fire in Boulder County, Colorado (September 6-10, 2010) burned 23 percent of the Fourmile Creek Watershed (10 square miles or 2,600 hectares), destroyed more than 160 homes, and was one of the costliest wildfires in Colorado history (figs. 1 and 2). The wildfire left the area at risk of substantial erosion (Ruddy and others, 2010), potentially degrading the water supply of the communities of Pinebrook Hills and Lafayette, which draw water from Fourmile Creek and Boulder Creek downstream of the burned area (fig. 2). Mine tailings and waste rock from historical placer and lode mining

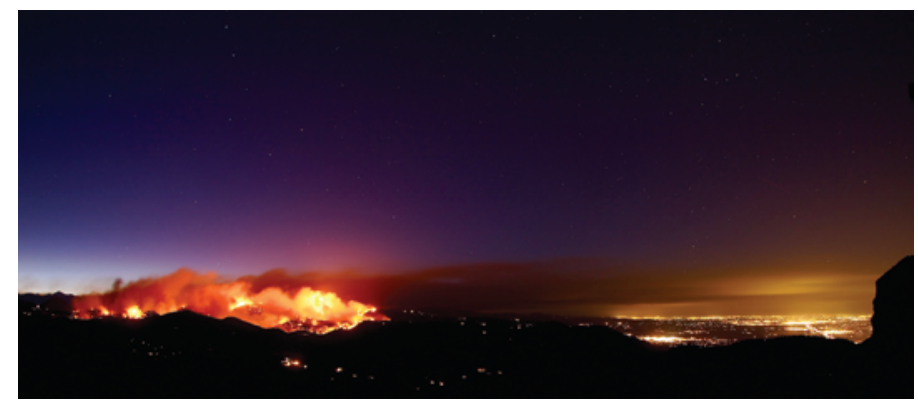

Figure 1. Fourmile Canyon wildfire burned 160 homes and degraded the source-water supply of two communities. (Photograph courtesy of Dan Lack, Cooperative Institute for Research in Environmental Sciences (CIRES), September 5, 2010).

are widely distributed in the Fourmile Creek watershed, and increased erosion could potentially transport these materials into downstream water bodies.

Water-quality monitoring sites were established on Fourmile Creek at 5 locations, 2 upstream (FCCR, FCLG) and 3 downstream (FCWM, FCLM, FCBC) of the burned area (fig. 2). Because water quality is closely tied to the hydrologic cycle, water samples were collected monthly during base flow, twice weekly during snowmelt runoff, and more frequently during storm events. Water samples were analyzed for dissolved organic carbon (DOC), nutrients, turbidity, major ions, and metals associated with mine waste (such as cadmium, lead, iron, manganese, and zinc). Water level, temperature, and specific 


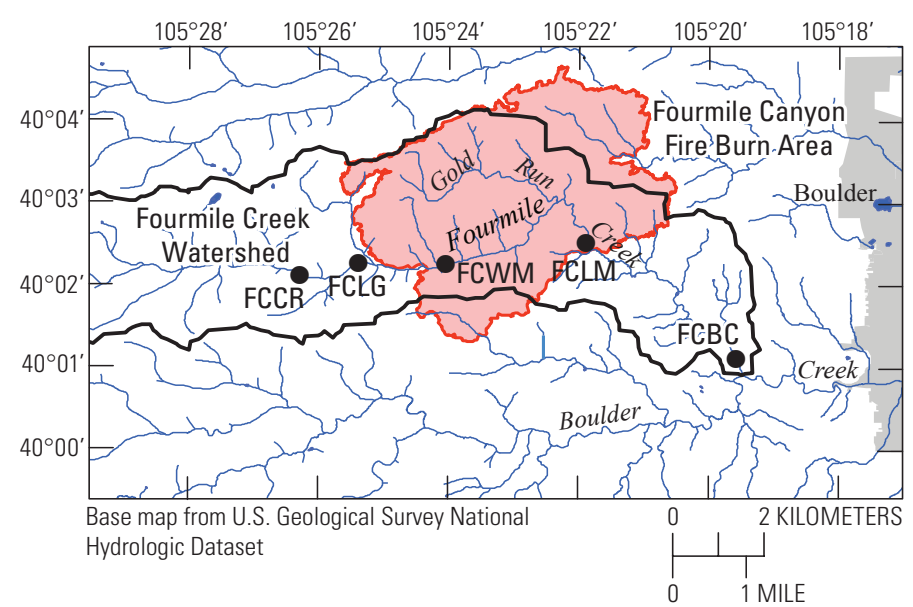

Figure 2. Area of Fourmile Canyon burn and water-quality sample sites.

conductivity were continuously monitored. Selected findings from the study are summarized here; for more detail, see McCleskey and others (in press); Murphy and others (2012); and Writer and others (2012).

\section{Results}

\section{Hydrologic Response to Postfire Precipitation Events}

Stream runoff in spring 2011 rose later than in previous years, primarily due to low snowfall in the winter and early spring (fig. $3 A$ ). Low-intensity rain and mixed snow-and-rain events in May and June 2011 (fig. 3B) generally increased discharge similarly upstream and downstream of the burned area. In contrast, thunderstorms on July 7 and July 13, 2011, shed less total rain but did so at much higher intensities. These storms produced short-term flash floods; discharge downstream of the burned area was as much as 8,000 percent above prestorm discharge. Upstream of the burned area, stream discharge during these storms increased by less than 50 percent. During the July 13 thunderstorm, stream discharge increased from 30 to 800 cubic feet per second in less than 5 minutes (fig. $4 A$ ), and peak discharge was three times as great as previously recorded for Fourmile Creek (U.S. Geological Survey, 2011). The July storms were generally typical of Colorado Front Range thunderstorms (storms of this size have a 20-50 percent chance of occurring each year), yet the stream's response to these storms provides clear evidence that burned watersheds are prone to flash floods that transport substantial amounts of sediment to downstream water bodies. This phenomenon has been observed in other burned watersheds in the Colorado Front Range (Moody and Martin, 2001).

\section{Water-Quality Response to Postfire Precipitation Events}

Variable source-water quality presents challenges for drinking-water providers. Drinking-water treatment processes operate more effectively when source-water quality is constant, DOC concentrations are below 5 milligrams per liter ( $\mathrm{mg} \mathrm{L}^{-1}$ ), and turbidity (an indicator of suspended material) is less than 20 nephelometric turbidity units (NTU). Elevated
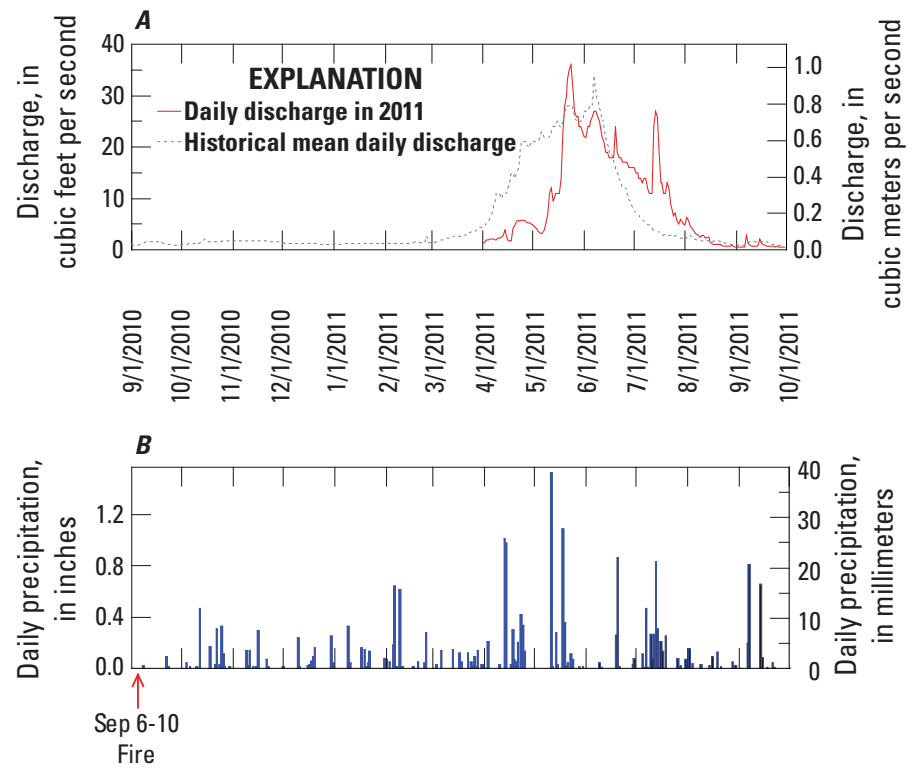

Figure 3. $A$, Mean daily discharge in 2011 and historical mean daily discharge, Fourmile Creek (at site FCBC). $B$, Daily precipitation. Data from Murphy and others, 2012.

nitrate concentrations can promote algal growth in water supply reservoirs, which can increase DOC concentrations and lead to disagreeable taste and odor.

"First flush" storm. The first substantial postwildfire precipitation event in the burned area fell on October 12, 2010, one month after the fire. The storm delivered relatively little precipitation and was of low intensity (fig. $3 B$ ). DOC concentrations downstream of the burned area increased from a baseflow value of $1.5 \mathrm{mg} \mathrm{L}^{-1}$ to as much as $17 \mathrm{mg} \mathrm{L}^{-1}$ (fig. $4 B$ ); the higher value exceeded the $5 \mathrm{mg} \mathrm{L}^{-1}$ treatment threshold. Nitrate concentrations increased from base-flow levels of less than 0.1 to as much as $1.3 \mathrm{mg} \mathrm{L}^{-1}$ (fig. 4C). Turbidity was not measured, but suspended material was visible in water samples (though at much lower concentrations than during thunderstorms in the following summer). Although no primary drinking-water standards for dissolved metals were exceeded, secondary drinking-water standards (which are related to aesthetic considerations, such as taste, color, and odor) for aluminum, iron, and manganese were exceeded downstream of the burned area.

Spring snowmelt. During snowmelt, DOC concentrations were similar (1-5 $\left.\mathrm{mg} \mathrm{L}^{-1}\right)$ at sites upstream and downstream of the burned areas. Nitrate concentrations increased from less than $0.02 \mathrm{mg} \mathrm{L}^{-1}$ to $0.75 \mathrm{mg} \mathrm{L}^{-1}$ downstream of the burned area during both spring snowmelt and low-intensity storms. Turbidity values were generally similar at upstream and downstream sites, except during the rain and mixed rain-and-snow events in May and June 2011, when turbidity downstream of the burned area increased from less than 10 NTU to as much as 800 NTU (fig. $4 D$ ). No increases in metal concentrations were observed that exceeded primary or secondary water standards.

Summer thunderstorms. The thunderstorms on July 7 and July 13, 2011, transported substantial amounts of sediment from hillslopes to Fourmile Creek (fig. 5). Large increases in concentrations of DOC (greater than $70 \mathrm{mg} \mathrm{L}^{-1}$ ) and of nitrate (greater than $9 \mathrm{mg} \mathrm{L}^{-1}$ ) and in turbidity (as much as 50,000 NTU) were measured downstream of the burned area. The total loading 
(defined as concentration times discharge) of nutrients and DOC transferred from burned areas to the stream was 1 to 2 orders of magnitude as great as loading from unburned areas. This large increase in sediment, carbon, and nutrient loading from burned watersheds has the potential to profoundly influence downstream water treatment processes, water-supply reservoirs, and aquatic ecosystems. Metal concentrations increased but did not exceed primary drinking-water standards. Iron and manganese exceeded secondary drinking-water standards during storm events, and concentrations of manganese remained elevated for several weeks after the storms. Although the observed manganese concentrations (as much as $0.49 \mathrm{mg} \mathrm{L}^{-1}$ ) do not pose a health risk, those increased concentrations can pose watertreatment problems and can foster the growth of microorganisms in reservoirs and distribution systems.

On the basis of one year of research, low-intensity rain events and spring snowmelt runoff produced minor increases in some water quality indicators. High-intensity thunderstorms 10 months after the wildfire, however, caused substantial change in water quality. Continued monitoring of Fourmile Creek would help hydrologists evaluate how water quality changes as the burned watershed recovers.
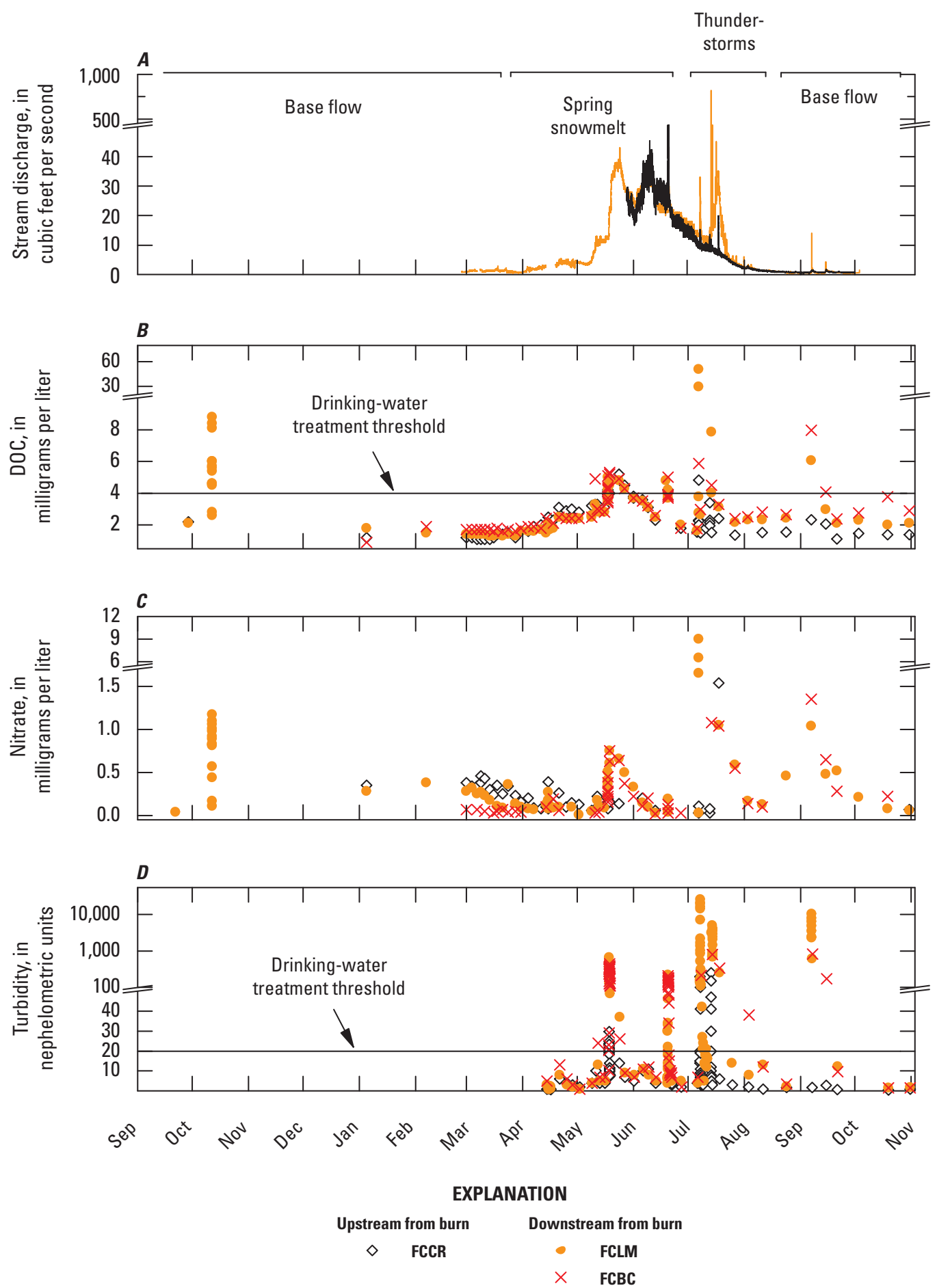

Figure 4. Stream discharge at 5-minute intervals and selected water quality characteristics in 2010-2011 measured in Fourmile Creek, Colorado, at monitoring stations FCCR, FCLM, and FCBC. 


\section{Implications for Drinking-Water Treatment}

Drinking-water utilities strive to provide safe drinking water for their communities. Management practices at a given utility commonly are based on past experience at individual treatment plants. Unfortunately, the unpredictable nature of wildfire makes it challenging to develop treatment-plant-specific strategies for treating source water degraded by the effects of wildfire. Findings from this study are likely applicable to other Colorado Front Range watersheds. Highintensity rainfall events in steep, burned watersheds are likely to move large amounts of suspended and dissolved material into downstream water supplies. The following problems may result:

Increased sediment loading of water-supply reservoirs, shortened reservoir lifetime, and increased maintenance costs;

Increased nutrient loading of reservoirs, which may promote algal blooms and associated disagreeable taste and odor;

Increased turbidity (cloudiness caused by suspended material) or increased iron and manganese concentrations, which may increase chemical treatment requirements and produce larger volumes of sludge, both of which would increase operating costs;

Increased dissolved organic carbon concentrations, which during disinfection may help form unwanted by-products (for instance, regulated carcinogens such as chloroform and trihalomethanes).

During high-intensity storms after a wildfire, sediment, nutrients, and organic carbon may be delivered to drinkingwater plants or water-supply reservoirs at concentrations higher than observed previously, and those high concentrations may last many years. Source-water-quality problems lasted more than 5 years after the 2002 Hayman fire west of Denver, Colorado (Rhoades and others, 2011) and nearly a decade after a wildfire in the Canadian Rockies (Emelko and others, 2011). Monitoring of source water downstream of burned watersheds may allow water managers to minimize objectionable effects, as by temporarily diverting some water or changing source water.

\section{References Cited}

Emelko, M.B., Silins, U., Bladon, K.D., Stone, M., 2011, Implications of land disturbance on drinking water treatability in a changing climate-Demonstrating the need for "source water supply and protection" strategies: Water Research, v. 45, p. 461-472.

McCleskey, R.B., Writer, J.H., and Murphy, S.F., in press, Water chemistry data for surface waters affected by the Fourmile Canyon wildfire, Colorado, 2010-2011: U.S. Geological Survey Open-File Report 2012-1104.

Moody, J.A., and Martin, D.A., 2001, Initial hydrologic and geomorphic response following a wildfire in the Colorado Front Range: Earth Surface Processes and Landforms, v. 26, p.1049-1070.

Murphy, S.F., McCleskey, R.B., and Writer, J.W., 2012, Effects of flow regimes on stream turbidity and suspended solids after wildfire, Colorado Front Range, in Wildfire and water quality-Processes, impacts, and challenges, Conference in Banff, Canada, June 2012, Proceedings: Wallingford, Oxfordshire, U.K., International Association of Hydrological Sciences publication 354, p. 51-58.

Rhoades, C.C., Entwistle, Deborah, and Butler, Dana, 2011, The influence of wildfire extent and severity on streamwater chemistry, sediment and temperature following the Hayman fire, Colorado: International Journal of Wildland Fire, v. 20, p. $430-442$.
Ruddy, B.C., Stevens, M.R., Verdin, K.L., and Elliott, J.G., 2010, Probability and volume of potential post-wildfire debris flows in the 2010 Fourmile burn area, Boulder County, Colorado: US Geological Survey Open-File Report 2010-1244. 5 p., accessed January 2012 at http://www.udfcd.org/FWP/ F2P2_Reports/FMCfire/USGS/OF10-1244.pdf.

U.S. Geological Survey, 2011, National Water Information System (NWISWeb): U.S. Geological Survey database accessed 15 December 2011 at http://waterdata.usgs.gov.

Westerling, A.L., Hidalgo, H.G., Cayan, D.R., and Swetnam, T.W., 2006, Warming and earlier spring increase Western U.S. forest wildfire activity: Science v. 313, p. 940-943.

Writer, J.H., McCleskey, R.B., and Murphy, S.F., 2012, Effects of wildfire on source-water quality and aquatic ecosystems, Colorado Front Range, in Wildfire and water qualityProcesses, impacts, and challenges, Conference in Banff, Canada, June 2012, Proceedings: Wallingford, Oxfordshire, U.K., International Association of Hydrological Sciences publication 354, p. 117-122.

\section{For Further Information}

Contact Jeffrey H. Writer (jwriter@usgs.gov; https://profile.usgs.gov/jwriter/) or Sheila F. Murphy (sfmurphy@usgs. gov; https://profile.usgs.gov/sfmurphy). 